\title{
Developing SciDiPro in the Implementation of 2013 Curriculum in SMK by Using Lesson Study
}

\author{
Sudji Munadi, Widarto, B. Sentot Wijanarka \\ Universitas Negeri Yogyakarta \\ Yogyakarta, Indonesia \\ sudji.munadi@uny.ac.id
}

\begin{abstract}
This research aims to develop learning media in the form of mobile device, instructional module, and job sheets. This research also managed to implement scientific-based learning to support the implementation of 2013 curriculum by using lesson study. Research and Development by Richey \& Klein (2010) and ADDIE (Branch, 2009) models were used. Data were collected using interviews, questionnaire, and tests. The research instruments being used were interview guidelines, questionnaire, and test questions. Qualitative and quantitative approach were taken to analyze the research data. The analysis result was tested internally and externally. The internal test showed the feasibility of the instruments, learning materials, and the media which was used in the teaching and learning process. The external test showed that the implementation of the learning media in the learning process was effective and gained a positive response from the students. The implementation of lesson study using scientific approach yielded a better learning attitude of the students in the second meeting compared to the first meeting.
\end{abstract}

Keywords: 2013 curriculum; lesson study; SciDiPro learning

\section{INTRODUCTION}

Education is essentially aimed at improving the intelligence of the nation's children. This essence have been mandated in the Undang-Undang No 20 Tahun 2003 [1] about National Education Systems which is hoped to realize the development process of the students' personal qualities as future generations. An education system conceptualized in curriculum should be able to realize the students' personal qualities. The curriculum development today have been established by the government through the Education and Culture Ministry (Kemendikbud) and is known as Kurikulum 2013 (2013 curriculum). The decision to implement the 2013 curriculum is based on the aim to improve the earlier education system, which was the School Based Curriculum (KTSP).

The change towards the 2013 curriculum emphasized on the students' autonomy in their learning process. The students have to study more actively, so that they have more flexibility to explore the knowledge they are learning. The knowledge being learned is not taken for granted, but rather it have to be explored in depth so as to discover the true meaning of the knowledge. Therefore, sensitivity and curiosity toward what they are learning will rise. This is in line with what Kelly
(2009: 1) [2] had explained: one feature that characterized curriculum change in the latter part of the last century was the increased incidence of planning and preparation in curriculum development.

The hope to make the quality of education better by the implementation of the 2013 Curriculum is not without problems. Problems that still unresolved until 2015 are books distribution and promotion of the 2013 curriculum to the teachers. Book development and printing for students have not been successfully completed. Also for SMK, the distribution of the books for students have not been completed either. According to Hamid Muhammad, in the SMK level, there are 1000 schools targeted for the 2013 Ccurriculum implementation. Not more than 748 schools ( 75 percent) have completely received the 2013 curriculum books, and then 252 schools (25 percent) haven't completely received it. (http://kemdikbud.go.id/kemdikbud/node/ 4438). Because of this incidents, the SMK that have been implementing the 2013 curriculum cannot implement it thoroughly. There are even findings that teachers still implement KTSP curriculum even though the policy of the school enforced the implementation of 2013 curriculum.

The promotion of the 2013 curriculum which was initiated by Kemendikbud have not been received effectively by the teachers. Many teachers found the 2013 curriculum confusing. Promotion in the form of training for the 2013 curriculum sponsored by Kemendikbud is done gradually, causing many teachers have to wait to be trained. As an example, data from Yogyakarta Education Quality Assurance Institute (LPMP) (mentioned in table 1), as per June 2014, there are SMK teachers in all of DIY who already have the 2013 curriculum training. But, for the subjects in $\mathrm{C} 1, \mathrm{C} 2$ and $\mathrm{C} 3$ groups in the technology and engineering sector, the training for the implementation of 2013 curriculum have not been done yet by LPMP Yogyakarta.

The problems in the implementation of the 2013 curriculum need a comprehensive evaluation. The evaluation can be done by implementing learning process which is based on the 2013 curriculum. The learning process implemented in schools, especially in SMK, should use approaches and models which are parts of the 2013 curriculum. The approach includes scientific approach, and the model includes discovery 
model, project-based learning (PjBL), and Problem-based learning (PBL). All of the competency being developed in SMK use the scientific approach with a varying model which can be used for the learning process.

TABLE 1. Data of SMA/SMK teachers who already have the 2013 curriculum training in DIY as per June 2014

\begin{tabular}{|c|l|c|}
\hline No. & District/Municipality & Number of teachers \\
\hline 1 & Bantul & 590 \\
\hline 2 & Sleman & 741 \\
\hline 3 & Gunung Kidul & 535 \\
\hline 4 & Kulonprogo & 412 \\
\hline 5 & Yogyakarta & 539 \\
\hline \multicolumn{2}{|c|}{ Total no. of teachers } & $\mathbf{2 . 8 1 7}$ \\
\hline
\end{tabular}

The approach and the learning model need to be planned and implemented for achieving activeness and autonomy of the students in their learning process. The result of the implementation in theory or practice is evaluated so that the next learning process could be better. This learning process needs an effective teacher's involvement. Active involvement is not only performed by the teacher who teaches a certain subject, but it needs a collaboration among the teachers in planning, execution, and evaluation of the learning process. Lesson study is one kind of activity which promotes collaboration among teachers. This activity can form collaboration and mutual learning among teachers. Teachers can plan, do, and see the learning process, be it a theory or practice.

Intensive communication among teachers in lesson study influences the students. Lesson study makes the students enthusiastic to learn. This enthusiasm is shown by the high motivation and learning activeness. A study from Sumartono and Yus Setriarini (2011: 320) showed that on mathematics learning in SMPN 1 Sukorejo through school-based lesson study (LSBS). The descriptor result showed that the students' activeness in finishing all of the given task gained the highest average score of $93 \%$, even though other descriptors gained an average in the range of $75 \%$ to $80 \%$. This has signified that the LSBS had given high motivation to the students in their learning processes.

Lesson study which can influence the learning activeness and motivation corresponds with the goal of The 2013 Curriculum. Lesson study activity using the approach and model specified by the 2013 curriculum is hoped to develop students that are active, autonomous, and skillful, so that a learning enthusiastic atmosphere will be formed, especially for SMK students. The implementation of learning processes in lesson study activity can be carried out using a scientific approach, discovery learning model and problem-based learning (PBL). The Scientific approach emphasizes on facts or logic from the learning materials. Discovery learning model involves students to be creative in discovering information. PBL model plans the learning process based on problems that arise from the learning materials and can develop critical thinking in finding the solutions to the problems.
The approach and learning model being implemented is expected to improve students' knowledge, attitude, and skills. Students' competence in theory and practice produce a comprehensive assessment, especially in the machining field. Therefore, there is a need in developing lesson study activity which implements scientific approach, discovery learning model and problem-based learning (PBL). This learning concept, which can simply be called SciDiPro (Scientific, Discovery, and Problem Based Learning), is expected to support the implementation of the 2013 curriculum through a lesson study activity.

\section{RESEARCH METHODS}

This study incorporates Research and Development $(R \& D)$ type using Richey \& Klein (2010: 8) [3] model and ADDIE (Branch R. M., 2009:2) model. Richey \& Klein model uses 4 stages, namely analysis, design, development, and evaluation. Whereas ADDIE model uses 5 stages, namely analyze, design, develop, implement and evaluate.

The model test design used internal and external tests. Internal test were validation instrument, media, and subject materials. The validation was done by lecturer and teacher. The external test was done by implementing media in the learning process and measure the students' response to the use of the media. Data were collected by using questionnaire, tests, and interviews. Data collection technique being used was by using instruments, which are questionnaire instruments, test questions, and interview guideline.

\section{RESULT AND DISCUSSION}

The research emphasizes on developing SciDiPro learning model by using a mobile device, module, and job sheets. The development of a module on mill machining subject carried out in class XII of SMK N 2 Pengasih. This module implementation used project-based learning. The students analyze actively about spur gears in the mechanical drawing before the practice commenced.

Prior to the implementation, the module media was validated by experts. A lecturer validated the learning material and gave an average score of 4 (Good). Another lecturer validated the module as a media and gave a score of 3 (Good). The validation categorized the module in Good quality, and it can then be tried out to the students of class XII of Machining Department in SMK N 2 Pengasih. The module was implemented on producing spur gears with project based learning. The students were grouped into 4 groups to analyze the product to be machined. Calculations and procedures were discussed by the students prior to machining practice.

The implementation of the module on mill machining practice had received many responses from the students. About $95.6 \%$ of the students responded with an interest in using the module, while $2.2 \%$ stated they are not interested, and another $2.2 \%$ are undecided. When students were asked to rate the module, $20 \%$ stated that the module is very good and need no revision, $77.8 \%$ stated it is good and need some revision and $2.2 \%$ of the students gave no answer. 
Students' activity in mill machining practice resulted in $75 \%$ of average observation by the observer from the first meeting, and $86 \%$ in the second meeting. The first meeting was about milling theory and the second meeting was about how they manufacture the product. This is what had caused the increase in average observation. Students' activeness was higher when making the real product of spur gears. The observation results in general were that the students followed the learning processes actively, from taking notes, discussing in groups, doing calculations and producing the spur gears. A few students were not focused on the learning process when they were given the milling theory, but they still managed to orderly and actively follow the learning processes.

Another effort in media development was also achieved from mobile device. The media was developed based on the work of Richey \& Klein (2010: 8). The development of the media implemented a project-based learning on mechanics technology and machine elements subjects. The research began with a need analysis which yielded:
1. The learning material in the media should cover 1 semester,

2. There should be an example of the learning material and test questions in the form of animation in the media,

3. There should be a grading system which is accessible to the teachers and students alike,

4. Quizzes should be in multiple choice questions,

5. Quizzes should be different or shuffled for each student,

6. The media should be interactive,

7. The students should sign-in and sign-out every time they use the media.

The design process used use-case diagram (Figure 1). Usecase diagram depicts all of the actors with their respective scenarios. It can be seen from the diagram, this learning media has two actors, which are students and teachers. Students can access the learning material, giving reviews, access the review timeline and undertake a quiz through use-case login. Teachers can access the learning materials, giving reviews, and access the grade list through the use-case login.

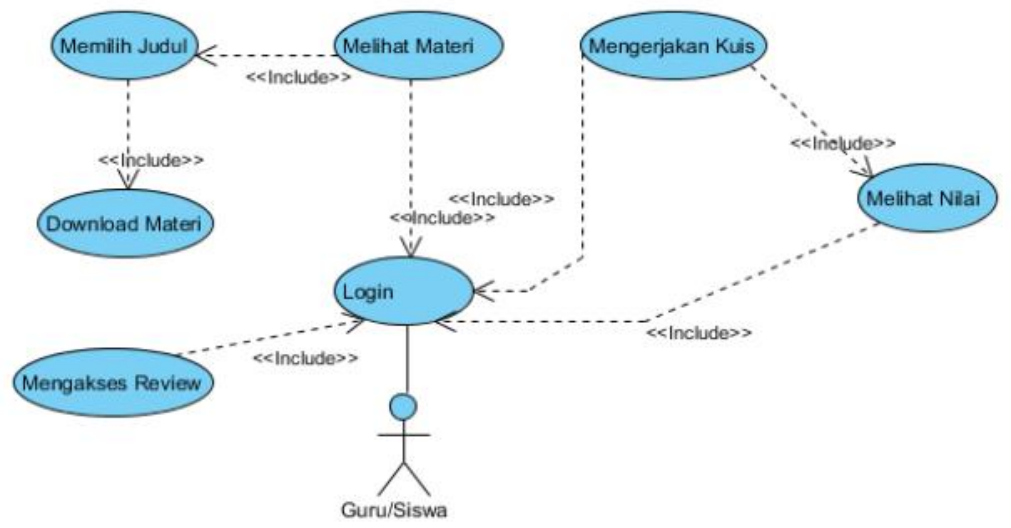

Figure 1. Use-case System diagram

The development process which is based on the need assessment result, design, and literatures is a reference in developing mobile device aided learning media product on Engineering Mechanics and Machine Elements theory. Specifications of the mobile device media product is listed in Table 2.

TABLE 2. Product Specification

\begin{tabular}{|c|c|c|}
\hline Menu Specification & Contents & Function \\
\hline Log out & User \& password & Exit from the apps \\
\hline Review & $\begin{array}{l}\text { Discussion and } \\
\text { download }\end{array}$ & $\begin{array}{l}\text { Student discussion } \\
\text { and material for } \\
\text { download }\end{array}$ \\
\hline Learning materials & $\begin{array}{l}\text { Machine elements } \\
\text { and mechanics }\end{array}$ & $\begin{array}{l}\text { Source materials, } \\
\text { texts and video exist }\end{array}$ \\
\hline Grade list & Students' grade & $\begin{array}{l}\text { Access the students' } \\
\text { score }\end{array}$ \\
\hline Quiz & $\begin{array}{l}20 \text { multiple choice } \\
\text { questions }\end{array}$ & $\begin{array}{l}\text { Evaluates the } \\
\text { learning process }\end{array}$ \\
\hline Competency & Basic competency & Discussion scope \\
\hline
\end{tabular}

The evaluation was carried out using the product's internal and external try-outs. The evaluation result was the instrument validation and the product was considered "feasible". The validation by the experts in learning materials resulted in validation score of 3.51 (very good), 3.18 (good), and 3.53 (very good). The expert in learning media validated with a score of 3.09 (good). The students' learning effectiveness using pre-test and post-test showed a difference between the experiment and the control group. The experiment group gained an average score of $77.39 \%$ (effective) and the control group gained $46.1 \%$ (fairly effective). On the students' response towards the learning media, 22 responded very well, 7 responded well, and only 3 responded poorly. The overall students' response towards the mobile device aided learning media gained an average score of 3.27 with a category of very good.

Subsequent research to support SciDiPro learning model was the development of job sheets for Computer Aided Design (CAD) subject using project-based learning. Data were collected at SMK N Sedayu on class XI of Machining Study Program. The research used the 4 stages of Richey and Klein (2010) model, which are: analysis, design, development, and evaluation.

The analysis stage uncovered that the students are having difficulties to comprehend mechanical drawing when they use 
CAD media. The design stage produced a job sheet design which can improve the students' analysis capability and the comprehension of mechanical drawings to be drafted in CAD. The development process, which is based on the need assessment, design, and literatures, is a reference in developing job sheet as a learning media on CAD subject.

Evaluation was generated from the internal and external product trial. The evaluation result was an instrument product considered as "feasible"; the validation of the learning media was a 3.52 score (good); the learning effectiveness of the students using project-based learning gained an average score of $80.1 \%$, which is considered effective. On the students' response towards the learning media, 24 students responded very well, 6 responded well, and 2 responded poorly. The average score of total students' response towards the job sheet of the CAD subject was 3.32 which is in the category of very good.

The next step in the research was the implementation of lesson study on KMKE subject using a scientific approach. The implementation was carried out in class $\mathrm{X}$ of Welding Study Program at SMK N Sedayu Bantul. The learning process can be described as follows:

1. The teacher delivers the introduction and learning objectives

2. The teacher split the students into 8 groups.

3. The students have a discussion with their respective group.

4. Each group observe by understanding the task given by the teacher. For further observation, the students search for information on the internet.

5. Each group should ask the teacher for any question regarding the given task.

6. Each group tried using some electrical components.

7. Each group did the analysis based on observation, asking questions, and trying out.

8. Each group write a report and presented their discussion results.

The learning process resulted in learning attitude of the students, which was observed by the observers. Each group of 8 members were observed by one observer. In the first meeting, the students' learning attitude were about $71.7 \%$, while in the second meeting it was $85.52 \%$. The increase in the learning attitude was because in the second meeting there were presentation of the discussion results and question and answer sessions. These activities had improved the students' activeness in following the lessons.

\section{SUMMARY AND RECOMMENDATION}

The discussion above can be summarized as follow:

1. The development of module for mill machining practice resulted in the feasibility of the instrument, learning materials and learning media. The implementation of the media in the teaching and learning process was effective and students responded very well to the module media.

2. The development of mobile device aided learning media on Mechanics and Machine Elements subject resulted from the validation of learning materials instrument and product. The media was validated as feasible to use. The implementation of the media was effective and the response from the students towards the learning media was very good.

3. The development of the job sheet using project-based learning on CAD subjects resulted in the validation of product and learning media which were feasible to use. The effectiveness of the students learning by projectbased learning was effective and the students responded well to the job sheet learning media.

4. The implementation of lesson study on KMKE subject using scientific approach improves the learning attitude, with an increase from $71.7 \%$ on the first meeting to $85.52 \%$ on the second meeting.

Recommendation

The recommendations from the development of this research are:

1. Improve the referencing effort by citing International books and journals so that the articles from the research's result will be acceptable on national and international journals.

2. Improve on lesson study team members who implement the learning process so that the research results are in accordance to the lesson study principles.

\section{REFERENCES}

[1] Departemen Pendidikan Nasional. (2003). Undang-Undang Republik Indonesia Nomor 20 Tahun 2003 Tentang Sistem Pendidikan Nasional. Jakarta: Depdiknas.

[2] Kelly, A.V. (2009). The Curriculum: Theory and Practice. New York: Sage Publication, Inc.

[3] Richey, Rita C. Klein. (2010). Design and Development Research. London: Lawrence Erlbaum Associates. Inc. 